\title{
Behaviour of fresh cut broccoli under different modified atmosphere conditions
}

\author{
Paola Fernanda Argüello Hernández ${ }^{1,2}$, María Concepción Ayuso Yuste ${ }^{3 *}$, David González-Gómez ${ }^{2,4}$, \\ Diego Bohoyo Gil2, Jonathan Delgado-Adámez², María Josefa Bernalte García ${ }^{3}$ \\ ${ }^{1}$ Escuela Superior Politécnica de Chimborazo, Panamericana Sur km. 1 1/2, Riobamba (Ecuador), ${ }^{2}$ Technological Institute of Food and \\ Agriculture (INTAEX-CICYTEX), Avd. Adolfo Suárez s/n, 06071 Badajoz (Spain), ${ }^{3}$ Agriculture Engineering School, University of Extremadura, \\ Avda. Adolfo Suárez s/n, 06007 Badajoz (Spain), ${ }^{4}$ Department of Science and Mathematics Education, Training Teaching School, University of \\ Extremadura, Avd. de la Universidad s/n, Cáceres (Spain)
}

\section{A B S T R A C T}

Fresh cut broccoli is a product with an increasing demand due to its convenience and proved benefits on human health, but is very perishable due to its high respiration rate. In order to maintain quality and extend shelf-life, two different approaches were carried out. Firstly, samples were packaged in sealed trays under passive modified atmosphere, and half of them were heated with air $\left(48^{\circ} \mathrm{C}\right.$ for 3 hours). All trays were stored at $5{ }^{\circ} \mathrm{C}$, and analyzed at $0,7,14$ and 21 days. Basic physical-chemical parameters, chlorophyll a and b concentration, total phenolics, antioxidant activity, microbiological and sensory quality were assessed. Results showed that heat treated broccoli showed poor sensory quality due to off-odors and no increase in the shelf-life of the product was observed. For this reason, a second experiment was carried using passive and active modified atmospheres $\left(10 \% \mathrm{O}_{2}\right.$ and $\left.5 \% \mathrm{CO}_{2}\right)$ and compared to a control in air. Samples were also stored at $5{ }^{\circ} \mathrm{C}$ and analyzed at 0, 5, 10 and 21 days. Modified atmosphere, either active or passive, allowed maintaining broccoli florets shelf-life up to 21 days, with higher quality compared to the control, being most suitable the passive modified atmosphere due to its simplicity and lower cost.

Keywords: Brassica oleracea L. var. Italica cv. Parthenon; Heat treatment; Modified atmosphere packaging; Quality assessment; Shelf-life

\section{INTRODUCTION}

In recent years, conscious consumers have an increasing demand for healthy food. Broccoli (Brassica oleracea L. var italica) is an inflorescence highly valued due to its richness in glucosinolates, vitamins, antioxidants and other healthpromoting phytochemicals (Yuan et al., 2010). In fact, Verhoeven et al., (1996) in their review indicated that epidemiological studies have shown an inverse association between the consumption of Brassica vegetables and the risk of cancer.Broccoli is a very perishable vegetable, and postharvest technologies should be applied, as modified atmosphere packaging, to extend its commercial life (Fernández-León et al., 2013a, Caleb et al., 2016).

Moreover, consumers demand not only healthy food, but easy-to-cook and easy-to-eat products. In that sense, the demand on broccoli has increased particularly, and broad types of broccoli products are now available in the market
(Schreiner et al., 2007). Fresh-cut broccoli decays faster than intact heads. The quality loss is visually observed in symptoms such as loss of turgidity and yellowing (Izumi et al., 1996; Hansen et al., 2001; Eason et al., 2005, 2007; Fernández-León et al., 2013a).

Considering the above-mentioned factors, it is necessary to offer to the consumers a convenience product, and to evaluate different postharvest procedures aiming to preserve the quality of fresh-cut broccoli florets (Zhuang et al., 1995; Lemoine et al., 2008, 2009).

Heat treatment can be used as a postharvest technique to control pathongens, to modify tissue response to other types of stress and to maintain product quality during storage (Viña and Chaves, 2007), and it has shown evident advantages when compared with chemical treatments. Heat treatments have been successfully used in fresh cut vegetables as onion (Hong et al., 2000), celery (Viña and

\footnotetext{
${ }^{*}$ Corresponding author:

María Concepción Ayuso Yuste, Agriculture Engineering School, University of Extremadura, Avda, Adolfo Suárez s/n, 06007 Badajoz
}

(Spain). E-mail: cayuso@unex.es

Received: 21 July 2016; Revised: 03 February 2017; Accepted: 05 February 2017; Published Online: 15 February 2017 
Chaves, 2007), leek (Tsouvaltzis et al., 2006), melon (Luna Guzmán et al., 1999) and garlic (Cantwell et al., 2003). For broccoli, hot air or water can delay senescence in intact heads (Funamoto et al., 2002, Perini et al., 2017) and in fresh-cut product (Lemoine et al., 2008, 2009; Costa et al., 2005).

Modified atmosphere packaging has been studied in order to assess whether this postharvest storage condition is an appropriate alternative to maintain physico-chemical, microbiological and sensory quality of fresh-cut broccoli. It is commonly accepted that broccoli can be benefitted by $1-2 \% \mathrm{O}_{2}$ with $5-10 \% \mathrm{CO}_{2}$ atmospheres at a temperature range of $0-5{ }^{\circ} \mathrm{C}$, extending its shelf-life (Fernández-León et al., 2013b). However, it could be induced unpleasant sulfur-containing volatiles at these low $\mathrm{O}_{2}$ levels (Izumi et al., 1996). It has been proved that it is not necessary to have these strict conditions to extend the postharvest life of broccoli, as Fernández-León et al., (2013b) established that a controlled atmosphere with $10 \% \mathrm{O}_{2}$ and $5 \% \mathrm{CO}_{2}$ was very effective on maintaining the quality parameters of broccoli during 12 days. Moreover, Fernández-León et al., (2013a) found that modified atmosphere packaging with microperforated polypropylene at $5^{\circ} \mathrm{C}$ allowed the retention of quality and functional values of fresh-cut broccoli cv. 'Parthenon'.

The aim of this work was to evaluate shelf-life of fresh-cut broccoli. In a first study, it was proved if the heat treatment helps to maintain the quality in broccoli florets and in a second study, diverse modified atmosphere packagings were tested (passive, active and a control) in order to establish the most suitable procedure to preserve physico-chemical, microbiological and sensory quality of fresh-cut broccoli.

\section{MATERIALS AND METHODS}

The work was divided into two subsequent experimental steps; first, modified atmosphere packaging and heat treatment was applied in order to extend the shelf-life of fresh-cut broccoli, then, in a second assay, three different atmospheres were used with the same aim.

\section{Plant material}

Broccoli (Brassica oleracea var. italica; cv. Parthenon) heads were obtained in February from two local producers (CELAEX, Puebla de la Calzada and Cooperativa del Campo Juan XXIII, Villafranco del Guadiana) in Badajoz, Spain. In both trials, approximately $15 \mathrm{~kg}$ of product were immediately transported to the INTAEX laboratory after harvesting, and stored in refrigeration at $0^{\circ} \mathrm{C}$ until the next day, when they were processed. Heads were prewashed with tap water, and then separated into florets with a sharp knife. Subsequently, florets were sanitized with chlorinated water (150 $\mathrm{mg} \mathrm{L}^{-1}$ as sodium hypochlorite; $\mathrm{pH}=6.5$ ) for 3 min at $4^{\circ} \mathrm{C}$.

\section{Assays description}

In the first assay, after washing with chlorinated water, broccoli florets were centrifuged at $850 \mathrm{rpm}$ for $30 \mathrm{~s}$ using an industrial centrifuge (K50 100 Kronen, Kehl am Rhein, Germany) to eliminate excess water, and then approximately $200 \mathrm{~g}$ of broccoli florets were placed in rigid polipropilene $(\mathrm{PP})$ plastic trays $(12 \times 17 \times 5 \mathrm{~cm})$ which were thermally sealed on the top with a $35 \mathrm{~mm}$ thick PP film on an industrial packaging machine (Model VerpachkungsSysteme, Western, Germany), passive modified atmosphere (PMA).

Half of the sealed trays ( 3 replicates $\mathrm{x} 4$ sampling days) were randomly taken and stored at $5^{\circ} \mathrm{C}$ and $90-95 \% \mathrm{RH}$ (PMA), and the remaining sealed trays (3 replicates $\mathrm{x} 4$ sampling days) were treated with hot air $(\mathrm{H})$ at $48{ }^{\circ} \mathrm{C}$ for $3 \mathrm{~h}$ in a Memmert oven (Schwabach, Germany) and they were left at room temperature and then stored at $5^{\circ} \mathrm{C}$ and 90-95\% RH (PMA+H).

Three replicates per treatment and sampling time were prepared, and trays were kept at $5{ }^{\circ} \mathrm{C}$ and $90-95 \% \mathrm{RH}$. Quality analyses were conducted on the processing day and after 7,15 and 21 days of cold storage.

Taking into account the results obtained on the first assay, the second experiment was focused on modified atmosphere without heat treatment. Active (AMA) and passive (PMA) modified atmosphere were assayed, and compared to a control (Control).

In the second assay, broccoli florets were conditioning as in the first assay and 16 sealed trays were prepared as described above (PMA), other 16 trays were injected with a gas mixture $\left(10 \% \mathrm{O}_{2}\right.$ and $\left.5 \% \mathrm{CO}_{2}\right)$ and sealed (AMA), and the rest were sealed with the same plastic film and then macroperforations ( $2 \mathrm{~mm}$ diameter) were performed in order not to alter the atmospheric conditions (Control). All trays were stored at $5^{\circ} \mathrm{C}$ and $95 \% \mathrm{HR}$, and assayed on the processing day and after 5,10 and 21 days of storage.

\section{Physico-chemical analysis}

Head space gas composition. $\mathrm{O}_{2}$ and $\mathrm{CO}_{2}$ contents of all trays were measured using an $\mathrm{O}_{2}$ and $\mathrm{CO}_{2}$ meter PAK 12P (Control y Suministros S.A, Barcelona, Spain). Each tray was used for a single determination.

Weight of each tray was recorded at the beginning and after storage, with a $0.01 \mathrm{~g}$ accuracy balance (Mettler, Madrid, Spain) and weight loss was expressed as percentage. 
Firmness was measured using a Stable Micro Systems Texture Analyzer TA-XT2i (Stable Micro Systems, Aname, Spain) through a compression assay on ten broccoli florets per treatment. The force was applied to produce a $10 \%$ deformation with a $100 \mathrm{~mm}$ aluminium plate. Force/deformation curves were recorded using the computer program of the texture analyzer. Firmness was expressed as the maximum force $(\mathrm{N})$.

Color parameters $\left(\mathrm{L}^{*}, \mathrm{a}^{*}\right.$ and $\left.\mathrm{b}^{*}\right)$ were measured in color space CIELab and the hue angle $\left(\mathrm{h}^{\circ}\right)$ and Cromaticity $\left(\mathrm{C}^{*}\right)$ were then calculated. Measurements were performed with a Minolta CR-200 (Aquateknica, S.A., Madrid, Spain) using the illuminant D65, with diffuse illumination, a viewing angle of $0^{\circ}$ and a measurement circular area of $8 \mathrm{~mm}$ diameter. Measurements were performed in 2 different locations of 10 broccoli florets.

Chlorophyll $\mathrm{a}$ and $\mathrm{b}$ contents were determined using multivariate calibration by means of partial least squares (PLS) (Fernández-León et al., 2010). The results were expressed as $\mathrm{mg} 100 \mathrm{~g}^{-1}$ of fresh weight (fw).

The determination of total phenolic content (TPC) was performed according to Fernández-León et al., (2013b) from $5 \mathrm{~g}$ of broccoli homogenate. The results were expressed as $\mathrm{mg}$ of chlorogenic acid equivalents $100 \mathrm{~g}^{-1} \mathrm{fw}$.

Total antioxidant activity (TAA) was evaluated according to the procedure proposed by Cano et al., (1998) slightly modified using ABTS. Results were expressed as $\mathrm{mg}$ of Trolox equivalents $100 \mathrm{~g}^{-1} \mathrm{fw}$.

\section{Microbial analysis}

Microbiological analyses were carried out on fresh broccoli florets before $(\mathrm{F})$ and after disinfection with chlorinated water $(\mathrm{F}+\mathrm{D})$, and on each sampling time. To determine total coliform, Escherichia coli, aerobic mesophilic, psychrotrophic, and yeast and molds counts, standard enumeration methods ISO 4832:2006, NF V 08-053:1993, ISO 4833:2003, ISO 17410:2001 and ISO 7954:1988 were used (NogalesDelgado et al., 2013), and the results were expressed as $\log$ CFU g ${ }^{-1}$. The presence or absence of Salmonella spp. and Listeria monocytogenes was confirmed following EN ISO 6579: 2002 and EN ISO 11290-1:1996, respectively.

\section{Sensory evaluation}

The sensory analysis of fresh-cut broccoli was carried out by seven trained panelists in several fruit and vegetable products. Samples were evaluated at room temperature. Methodology by order of the UNE-ISO 8587:2010 was used. They were asked to order the samples by decreasing intensity of the following parameters: off-odors, color and appearance. For the first assay, they had also to group the samples by treatment.

\section{Statistical analysis}

For statistical studies SPSS 19.0 software was used (IBM SPSS statistic, USA). Data are expressed as means \pm SD and were analyzed using a one-way analysis of variance (ANOVA). When ANOVA detected significant differences between mean values, means were compared using Tukey's HSD test. For sensory data analysis, Friedman test was used, as described above. Sensory evaluation data were analyzed with Friedman statistical test, considering 13.69 as critical $\mathrm{F}$ value for a significance level of 0.01 , when working with 7 judges and 6 samples (Naes et al., 2010).

\section{RESULTS AND DISCUSSION}

\section{First experience}

Fig. 1 shows the atmosphere composition inside the packages during storage. $\mathrm{O}_{2}$ and $\mathrm{CO}_{2}$ evolution was

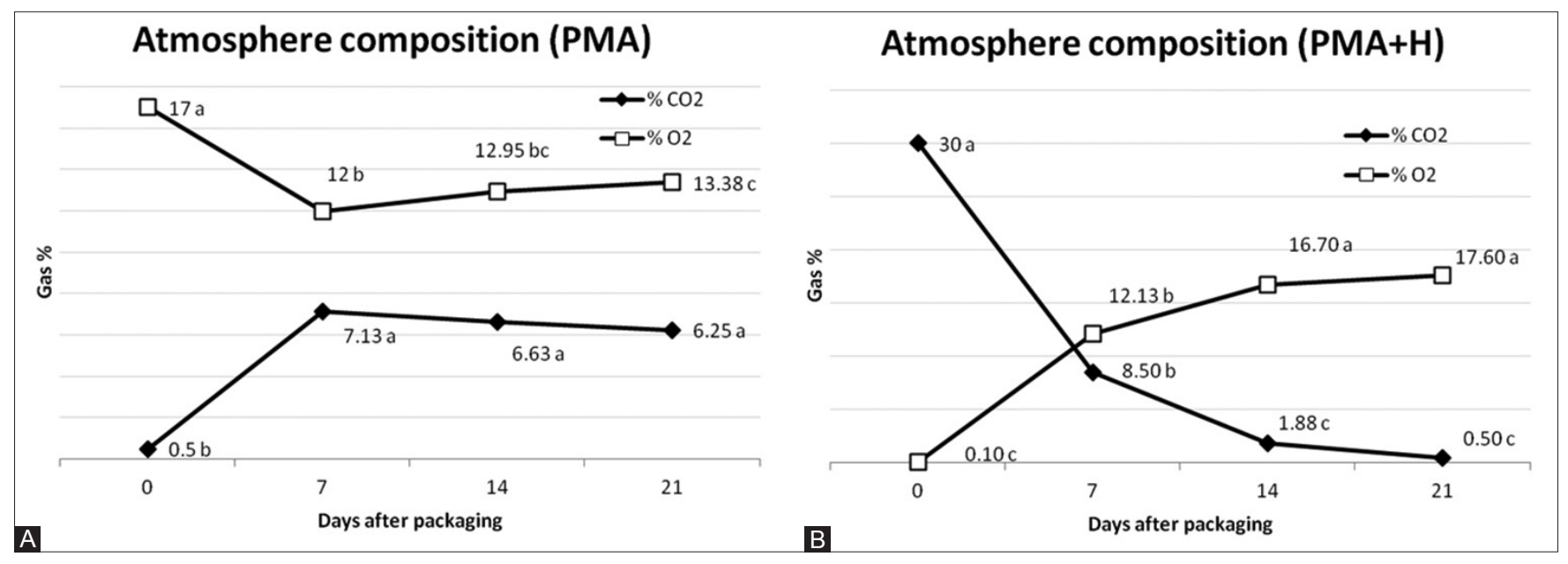

Fig 1. Gas composition within the trays of PMA $(A)$ and $P M A+H(B)$ during storage. Different letters for each gas and treatment indicate significant differences $(p<0.05 ; n=3)$. 
different in both treatments. In PMA (Fig. 1A), the percentage of $\mathrm{O}_{2}$ decreased and $\mathrm{CO}_{2}$ increased untill day 7 , due to the high respiration rate of broccoli florets, when gas equilibrium was reached and remained almost constant during storage, according to other authors (Jia et al., 2009). On the other hand, in PMA+H (Fig. 1B) the initial gas composition was very different from PMA treatment, as it was measured just after heating $\left(48^{\circ} \mathrm{C}\right.$ for $\left.3 \mathrm{~h}\right)$ which caused a high stress on broccoli florets. Accordingly, the respiration rate dramatically increased during heat treatment and the gas composition inside the trays reached values of $30 \% \mathrm{CO}_{2}$ and $0.1 \% \mathrm{O}_{2}$. During storage, $\mathrm{CO}_{2}$ concentration diminished and $\mathrm{O}_{2}$ increased up to day 14 , when gas equilibrium was reached and maintained until day 21. At the end of the storage, gas composition inside the $\mathrm{PMA}+\mathrm{H}$ trays was very similar to that of atmospheric air, which can be attributed to a permeability modification of the plastic due to the heat treatment.

Results of weight loss, color, firmness, chlorophylls, TPC and TAA are shown in Table 1 . There were significant differences between treatments in weight losses, being $\mathrm{PMA}+\mathrm{H}$ the treatment with the highest losses, although they were always lower than $1 \%$. Condensation inside the trays was also observed in this treatment. These results disagree with those of Lemoine et al., (2009), who found lower water losses in heat treated florets.

Initial broccoli florets showed a $C^{*}$ value of 4.60 , that increased after 7 days of storage in the two types of MA packages. After that, there was a decrease in MPA samples during storage, whereas MPA $+\mathrm{H}$ florets showed a slight increase. In all sampling days there were significant differences between both treatments (Table 1).

Among all color parameters, $h^{\circ}$ was the one that better describes the yellowish of the florets during storage, $\mathrm{h}^{\mathrm{o}}$ values close to 180 mean a greener color, as for fresh sample. There was a decrease since the first day of analysis, being the fall more drastic at day 21 , but it must be pointed out that there were no significant differences between treatments.

There was a significant firmness loss in heat treated samples $(\mathrm{PMA}+\mathrm{H})$ after 14 days of storage $(51 \%)$, that did not took place on PMA samples (21\%), that could be attributed to water losses.

The highest concentration of chlorophyll pigments ( $a$ and $b$ ) were found in fresh broccoli florets (13.10 and $3.23 \mathrm{mg} 100 \mathrm{~g}^{-1} \mathrm{fw}$, respectively) as they are very labile compounds. Chlorophylls decreased during storage with a decrement of $39 \%$ for chlorophyll a and $44 \%$ for chlorophyll b after 21 days at $5{ }^{\circ} \mathrm{C}$. Similarly, Lemoine et al., (2009) also found chlorophylls decreases in freshcut broccoli florets. At the end of the storage, PMA+H treatment had a higher concentration of chlorophylls pigments than PMA. In a similar way, Funamoto et al., (2002) found less yellowness in broccoli florets heated at $45^{\circ} \mathrm{C}$ for 14 minutes, and Büchert et al., (2011) also found higher chlorophyll contents in heat treated samples.

Phenolics are important compounds since they contribute to the maintenance of antioxidant status. Regarding to total phenols, PMA broccoli florets showed higher values than fresh sample (87.73 mg chlorogenic acid $\left.100 \mathrm{~g}^{-1}\right)$ although they were not significantly different. On the other hand, $\mathrm{PMA}+\mathrm{H}$ samples presented a $30 \%$ decrease after 21 days of storage at $5{ }^{\circ} \mathrm{C}$, and always exhibited differences with PMA. Lemoine et al., (2009) found an important decrease in phenolic in heat treated samples after 7 days of storage, and then levels slightly increased. They explained that behavior as a consequence of a decrease in the activity of phenylalanine ammonia lyase enzyme (PAL) that has been related to phenolic compounds synthesis. Roura et al., (2008) found a reduction in PAL activity in fresh-cut lettuce, after a short heat treatment (water at $50{ }^{\circ} \mathrm{C}$ during $2 \mathrm{~min}$ ).

Fresh broccoli exhibits a wide range of compounds with antioxidant activity that has been reported to maintain

Table 1: Weight loss, color, firmness, chlorophylls and total phenols in broccoli florets stored under modified atmospheres (PMA and $\mathrm{PMA}+\mathrm{H}$ )

\begin{tabular}{lccccccc} 
Treatment & FRESH & PMA & PMA+H & PMA & PMA+H & PMA & PMA+H \\
\hline Sampling date & 0 & & 7 & & 14 & & 21 \\
Weight loss & - & $0.11 \pm 0.13 \mathrm{c}$ & $0.54 \pm 0.12 \mathrm{ab}$ & $0.22 \pm 0.00 \mathrm{c}$ & $0.71 \pm 0.20 \mathrm{a}$ & $0.27 \pm 0.11 \mathrm{bc}$ & $0.66 \pm 0.18 \mathrm{a}$ \\
$\mathrm{C}^{*}$ & $4.60 \pm 2.33 \mathrm{a}$ & $17.22 \pm 7.24 \mathrm{c}$ & $15.42 \pm 2.08 \mathrm{c}$ & $9.93 \pm 2.77 \mathrm{~b}$ & $16.24 \pm 2.14 \mathrm{c}$ & $6.07 \pm 2.36 \mathrm{a}$ & $17.98 \pm 5.09 \mathrm{c}$ \\
$\mathrm{h}^{\circ}$ & $177.18 \pm 56.52 \mathrm{~d}$ & $148.01 \pm 7.18 \mathrm{c}$ & $146.05 \pm 2.36 \mathrm{c}$ & $146.35 \pm 10.98 \mathrm{c}$ & $144.75 \pm 3.11 \mathrm{bc}$ & $125 \pm 18.4 \mathrm{ab}$ & $116.45 \pm 6.93 \mathrm{a}$ \\
F max & $12.13 \pm 2.12 \mathrm{bc}$ & $11.98 \pm 1.78 \mathrm{bc}$ & $11.42 \pm 3.61 \mathrm{bc}$ & $9.63 \pm 1.28 \mathrm{~b}$ & $5.87 \pm 1.65 \mathrm{a}$ & $12.88 \pm 2.24 \mathrm{c}$ & $4.01 \pm 0.95 \mathrm{a}$ \\
Chlorophyll a $^{1}$ & $13.10 \pm 0.35 \mathrm{e}$ & $10.72 \pm 0.62 \mathrm{~d}$ & $9.59 \pm 0.3 \mathrm{c}$ & $9.54 \pm 0.04 \mathrm{bc}$ & $9.79 \pm 0.12 \mathrm{c}$ & $7.82 \pm 0.1 \mathrm{a}$ & $8.61 \pm 0.39 \mathrm{ab}$ \\
Chlorophyll b $^{1}$ & $3.23 \pm 0.15 \mathrm{~d}$ & $2.51 \pm 0.08 \mathrm{c}$ & $2.65 \pm 0.04 \mathrm{c}$ & $2.46 \pm 0.06 \mathrm{c}$ & $2.48 \pm 0.03 \mathrm{c}$ & $1.73 \pm 0.05 \mathrm{a}$ & $2.03 \pm 0.06 \mathrm{~b}$ \\
TPC $^{2}$ & $87.37 \pm 4.49 \mathrm{bcd}$ & $101.74 \pm 11.89 \mathrm{~d}$ & $83.99 \pm 1.03 \mathrm{bc}$ & $95.89 \pm 3.68 \mathrm{~cd}$ & $77.93 \pm 5.39 \mathrm{ab}$ & $92.68 \pm 3.92 \mathrm{bcd}$ & $67.08 \pm 6.98 \mathrm{a}$ \\
TAA $^{3}$ & $72.48 \pm 2.47 \mathrm{~d}$ & $67.52 \pm 1.95 \mathrm{~d}$ & $64.06 \pm 4.96 \mathrm{~cd}$ & $53.4 \pm 3.68 \mathrm{~b}$ & $54.92 \pm 5.25 \mathrm{bc}$ & $36.01 \pm 3.71 \mathrm{a}$ & $37.61 \pm 3 \mathrm{a}$ \\
\hline
\end{tabular}

${ }^{1}$ Expressed as mg $100 \mathrm{~g}^{-1}$ fresh weight. ${ }^{2}$ Expressed as $\mathrm{mg}$ chlorogenic acid $100 \mathrm{~g}^{-1}$ fresh weight. ${ }^{3}$ Expressed as mg Trolox $100 \mathrm{ml}^{-1}$ of broccoli extract. Values followed by different letters in the same row are significantly different $(\mathrm{p}<0.05)$ 
human health (Zhang and Hamauzu, 2004), so antioxidant activity is an important characteristic for broccoli quality. The highest TAA value corresponded to fresh sample, and there was a decrease during storage registering values 50 $\%$ lower after 21 days. No significant differences between treatments were found though storage.

Microbial counts were under the limit of detection of the method $\left(<1 \log _{\mathrm{UFC}} \mathrm{g}^{-1}\right)$ in all broccoli samples for total coliform and E. coli. Samples also showed absence of the pathogens Salmonella spp. and L. monocytogenes. Regarding aerobic mesophilic and psychrotrophic bacteria (Fig. 2 A, B), the behavior was similar; the sanitization process slightly reduced the counts that remained constant for PMA samples and during storage; while for heat treated broccoli florets $(\mathrm{PMA}+\mathrm{H})$ there was a significant reduction $(55 \%)$. Heat treatment may result in the hydrolysis and/ or thermal degradation of glucosinolates and various breakdown products are formed (isothiocyanates, nitriles, oxazolidinethiones, thiocyanate, and epithionitriles). Among the volatile products of glucosinolates degradation, isothiocyanates have been generally known as the most biologically active, being reported to possess broadspectrum biological activity against bacterial (Lin et al., 2000). The values obtained in the present work were similar to those found by Brackett (1989) and higher than those reported by others (Olarte et al., 2009; Ansorena et al., 2011; Martínez-Hernández et al., 2013).

There were no differences between treatments during the storage in counts of yeasts and molds. A significant reduction $\left(\sim 3 \mathrm{Log} \mathrm{UFC}^{-1}\right)$ was observed after sanitization and the first week of storage, increasing the counts afterwards. The heat treatment did not affect the viability of yeasts and molds.

Regarding to sensory evaluation, only the results for appearance are shown in Table 2. Off-odors and color results are not presented as they did not provide any additional information. There were significant differences between treatments, as the F test (13.72) was higher than the critical $F$ value $(13.69)$ of the Friedman's rank test $(p<0.01)$.

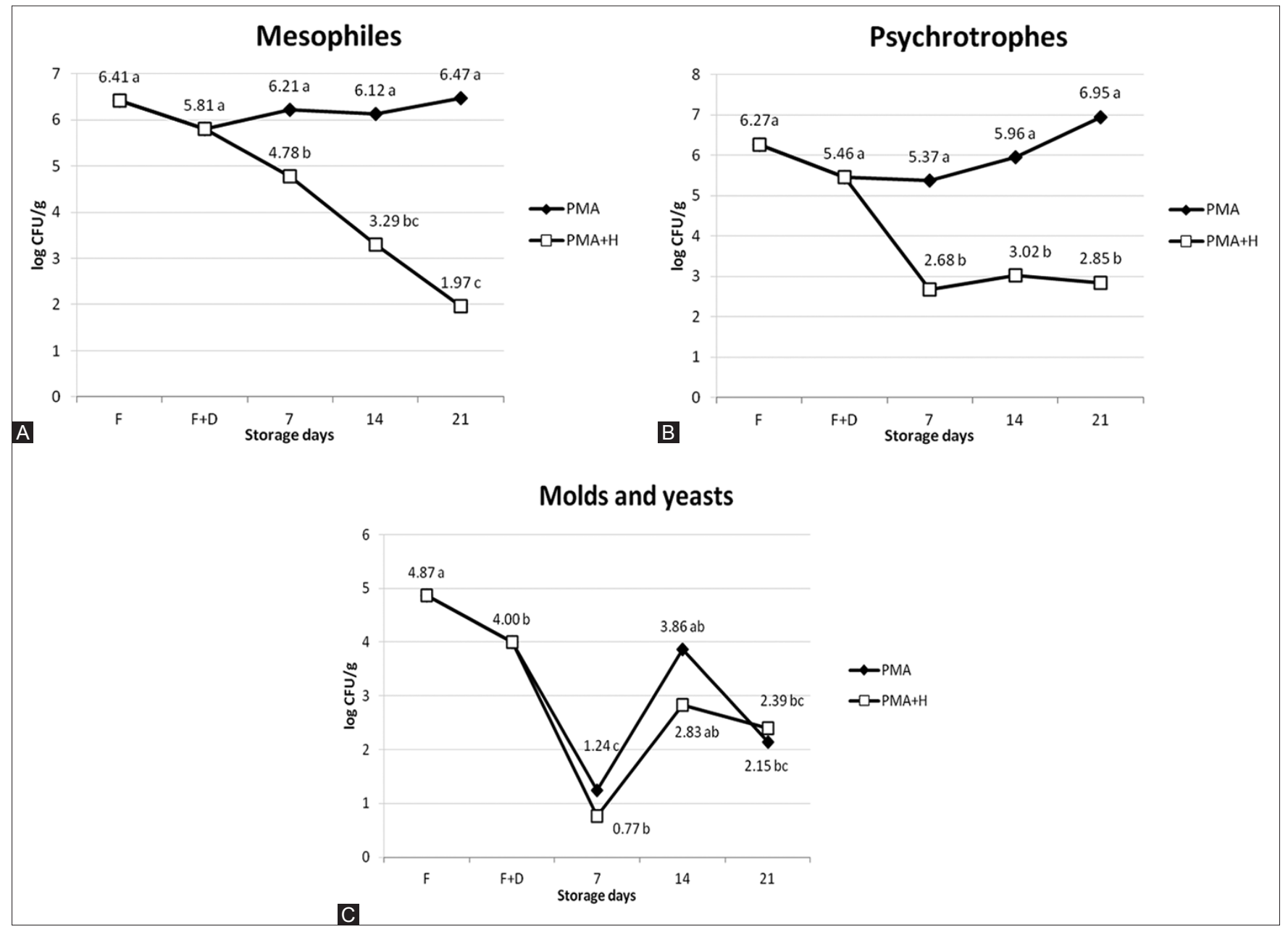

Fig 2. Microbial counts in $\mathrm{PMA}$ and $\mathrm{PMA}+\mathrm{H}$ fresh-cut broccoli samples, before $(\mathrm{F})$ and after disinfection $(\mathrm{F}+\mathrm{D})$, and during storage. Different letters for each treatment indicate significant differences $(p<0.05 ; n=3)$. 
The sum of the sample ranks $(\mathrm{R})$ in the PMA treatment ranged between 12.5 and 15.5 whereas in the PMA+H between 34 and 35.5. As the difference of rank sums between samples, on the same treatment over time, was less than calculated Least Square Differences $(L S D=13.72)$, there were no differences between them.

In the PMA $+\mathrm{H}$ for all sampling dates was observed water condensation, and the presence of off-odors, those were described as fungi, cheese, alcohol or moldy by the judges. Results indicate that panelists preferred PMA samples that exhibited better quality characteristics. So in the second experience, the study was focused on modified atmosphere, both active and passive.

\section{Second experience}

Fig. 3 shows the gas composition of the atmospheres around the florets. As expected, the gas composition of control samples did not change during storage and was similar to the atmospheric air due to the film macroperforations.

In the modified atmosphere packages, the equilibrium atmosphere was reached after 5 days and it was similar

Table 2: Results of the sensory test of PMA and PMA+H fresh-cut broccoli 'Parthenon' stored at $5^{\circ} \mathrm{C}$

\begin{tabular}{|c|c|c|c|c|c|c|c|c|c|c|c|c|c|c|c|c|c|c|}
\hline \multirow{3}{*}{$\begin{array}{l}\text { Treatment } \\
\text { Sampling date } \\
\text { Sample }\end{array}$} & \multicolumn{4}{|c|}{ PMA } & \multicolumn{2}{|c|}{$\mathrm{PMA}+\mathrm{H}$} & \multicolumn{3}{|c|}{ PMA } & \multicolumn{3}{|c|}{$\mathrm{PMA}+\mathrm{H}$} & \multicolumn{2}{|r|}{ PMA } & \multicolumn{4}{|c|}{$\mathrm{PMA+H}$} \\
\hline & & & & 7 & & & & & & 4 & & & & & & & & \\
\hline & A & B & C & $\mathrm{D}$ & $E$ & $\mathrm{~F}$ & $A$ & $\mathrm{~B}$ & C & $\mathrm{D}$ & $E$ & $\mathrm{~F}$ & A & B & C & $\mathrm{D}$ & $E$ & $\mathrm{~F}$ \\
\hline Rank sums (R) & 12.5 & 14 & 15.5 & 34 & 35.5 & 35.5 & 16.5 & 13 & 12.5 & 34.5 & 37 & 33.5 & 14 & 12.5 & 13.5 & 34.5 & 36 & 34.5 \\
\hline $\mathrm{R}$ mean per treatment & & 14 & & & 35 & & & 14 & & & 35 & & & 13.3 & & & 35 & \\
\hline Ftest per sampling date & 48.24 & & & & & & 48.65 & 5 & $\begin{array}{r}\text { ay 7) } \\
\text { LSD }=\end{array}$ & $\begin{array}{l}48.2 \\
13.72\end{array}$ & -11 & & 45.8 & & & & & \\
\hline
\end{tabular}

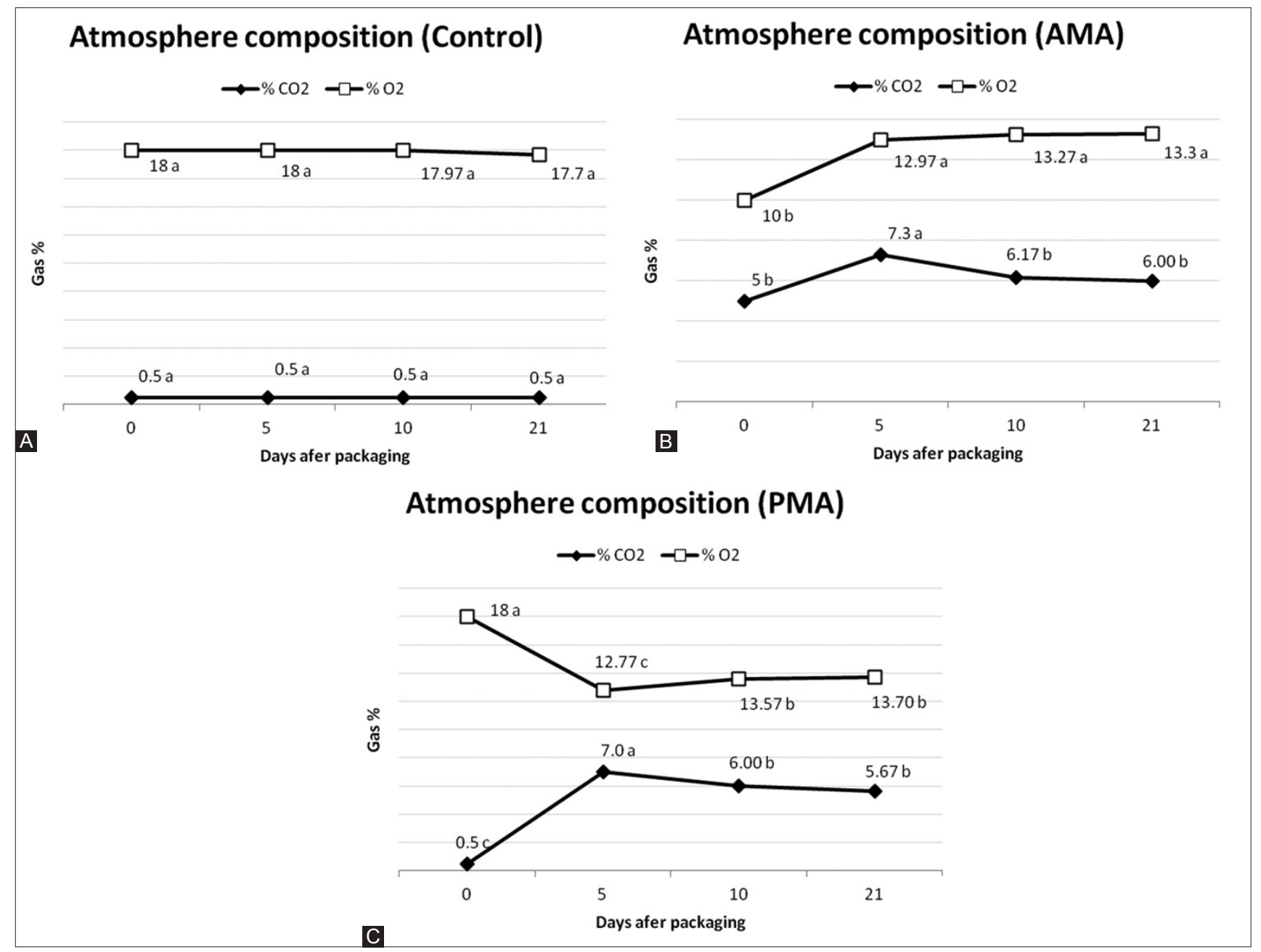

Fig 3. Gas composition within the trays of Control (A), PMA (B) and AMA (C) during storage. Different letters for each gas and treatment indicate significant differences $(p<0.05 ; n=3)$. 
in both treatments $\left(13 \% \mathrm{O}_{2}\right.$ and $\left.6 \% \mathrm{CO}_{2}\right)$, and remained almost constant up to the end of the storage. Similar results were obtained by Fernández-León et al., (2013a), using active modified atmosphere in broccoli with different plastic film.

As observed in Table 3, weight losses were always higher in Control samples, registering maximum levels of approximately $1 \%$ after 21 days of storage. Samples under modified atmospheres did not show differences between treatments. Weight losses of PMA and AMA samples were below $0.4 \%$, registering significant differences comparing to control samples only at the end of storage. Comparing with other works (Fernández-León et al., 2013a,b), the weight losses were relatively lower in our study. In control samples probably because of the use of a macroperforated film for sealing the trays, and in the modified atmosphere packages, the type of plastic film must be the responsible.

As it is well kwon, color is a very important quality attribute in broccoli as it is related to senescence processes that cause yellowing. Comparing to fresh sample, there was a diminishing in $\mathrm{h}^{\circ}$ and in $\mathrm{C}^{*}$ during storage in all treatments. Martínez-Hernández et al., (2013) had also previously reported a decrease in $\mathrm{h}^{\circ}$ for broccoli florets. In general, no differences in $\mathrm{h}^{\circ}$ and $\mathrm{C}^{*}$ were observed among control and AMA and PMA broccoli samples throughout cold storage.

Firmness did not show significant differences between control and modified atmosphere treatments through storage. There was a slight increase at the end of storage, as previously reported by Ansorena et al., (2011) for broccoli florets during air storage.

Chlorophylls content in broccoli samples are shown in Table 3. There was a reduction in chlorophyll a content during storage for all treatments. In broccoli florets of AMA and PMA trays, chlorophyll a was always higher than in control samples, although these differences were significant only on day 21 . On the other hand, the results showed that chlorophyll $\mathrm{b}$ remained without significant changes until day 5 for the control, while for the modified atmosphere samples (AMA and PMA) no significant differences were observed up to day 21 of cold storage. As it is known, chlorophyll a is responsible for blue-green colors while chlorophyll $\mathrm{b}$ is related to the yellow-green ones. The results obtained were slightly lower than other reported values (Fernández-León et al., 2013a,b). From the hereby presented data, it can be affirmed that the modified atmosphere treatments did not prevent chlorophylls degradation.

TPC evolution is summarized in Table 3. The initial TPC (87.58 $\mathrm{mg}$ chlorogenic acid $100 \mathrm{~g}^{-1} \mathrm{fw}$ ) in fresh broccoli

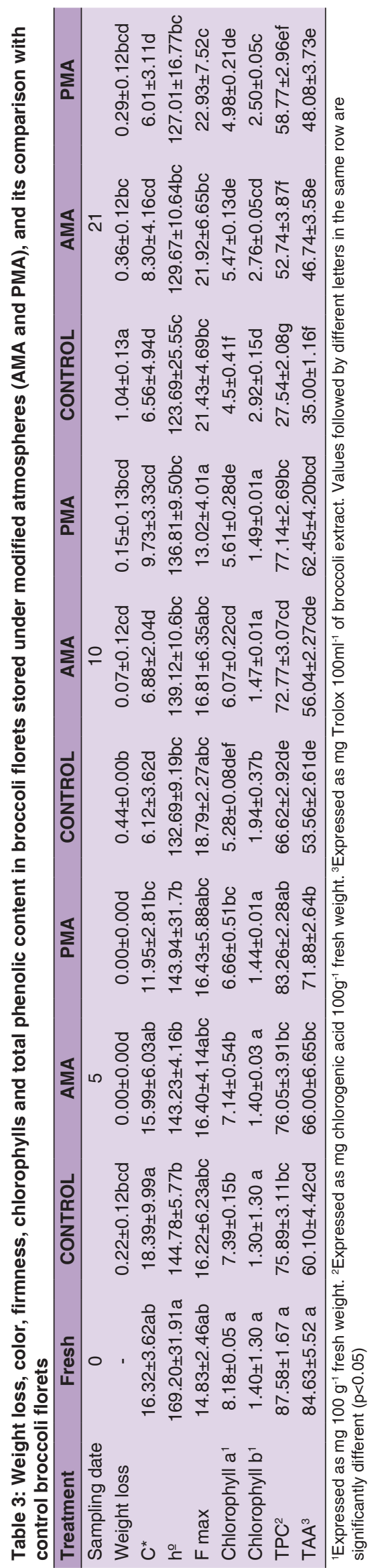

Emir. J. Food Agric • Vol $29 \bullet$ Issue 3 • 2017 
was the higher value among all samples, but lower to those reported in literature (Fernández-León et al., 2013b). During storage there was a decrease in phenol contents that was more pronounced in control samples, compared to modified atmospheres on day 21 (27.54 vs. 52.74 and $58.77 \mathrm{mg}$ chlorogenic acid $100 \mathrm{~g}^{-1}$ ), with no significant TPC differences between modified atmosphere treatments throughout storage. These differences could be explained by the high respiration rate of broccoli stored under air conditions (Izumi et al., 1996) that might increase the degradation of TPC (Vallejo et al., 2003).

The evolution of TAA was similar to that of TPC. These compounds have a strong antioxidant activity as previously described by Fernández-León et al., (2013a,b). At the end of storage, the control samples had the lowest TAA value, significantly different to those of modified atmospheres samples. These results agree with those of Serrano et al., (2006), who pointed out that modified atmosphere packaging was an effective treatment for maintenance of TAA and TPC of broccoli during refrigerated storage.

As in the first assay, total coliform and E. coli counts were under the limit of detection of the method $\left(<1 \mathrm{Log} \mathrm{UFC}^{-1}\right)$ and also showed absence of Salmonella spp. and $L$. monocytogenes in all broccoli samples. The low initial levels of microorganisms together with other production conditions are responsible for a high quality final fresh-cut product. Aerobic mesophilic and psychrotrophic bacteria showed a similar behavior (Fig. 4), with a reduction (1-2 Log UFC $\mathrm{g}^{-1}$ ) after the sanitization process and an ulterior increase. In general there were no important differences among treatments with a result slightly lower for AMA at day 21. Our results were similar or lower than the reported by Lucera et al., (2011) and Martínez-Hernández et al., (2013). Yeats and molds counts also decreased (1.5 Log UFC $\left.\mathrm{g}^{-1}\right)$ after sanitization, and the levels remain almost constant during storage (Fig. 4).

Regarding to sensory evaluation, as in the first experience, color loss, off-odor development and aspect were evaluated by a panel during the storage period, and these parameters had similar behavior. No significant differences among the three treatments were detected by panelist until day 21, and in Table 4 are shown only the results for aspect at that date. There were significant differences between treatments, as F test (46.67) was higher than the critical F value (13.69). In order to detect the samples that were different, it was compared the rank sum of the treatment with the LSD value (13.72). Differences between the rank sums of control and modified atmosphere treatments (AMA and PMA) were 23 and 29, respectively, higher than LSD and consequently different to control. On the other hand there was no significant difference between rank sum of AMA and PMA. In general, control samples were the worst valued, as they showed larger color loss,

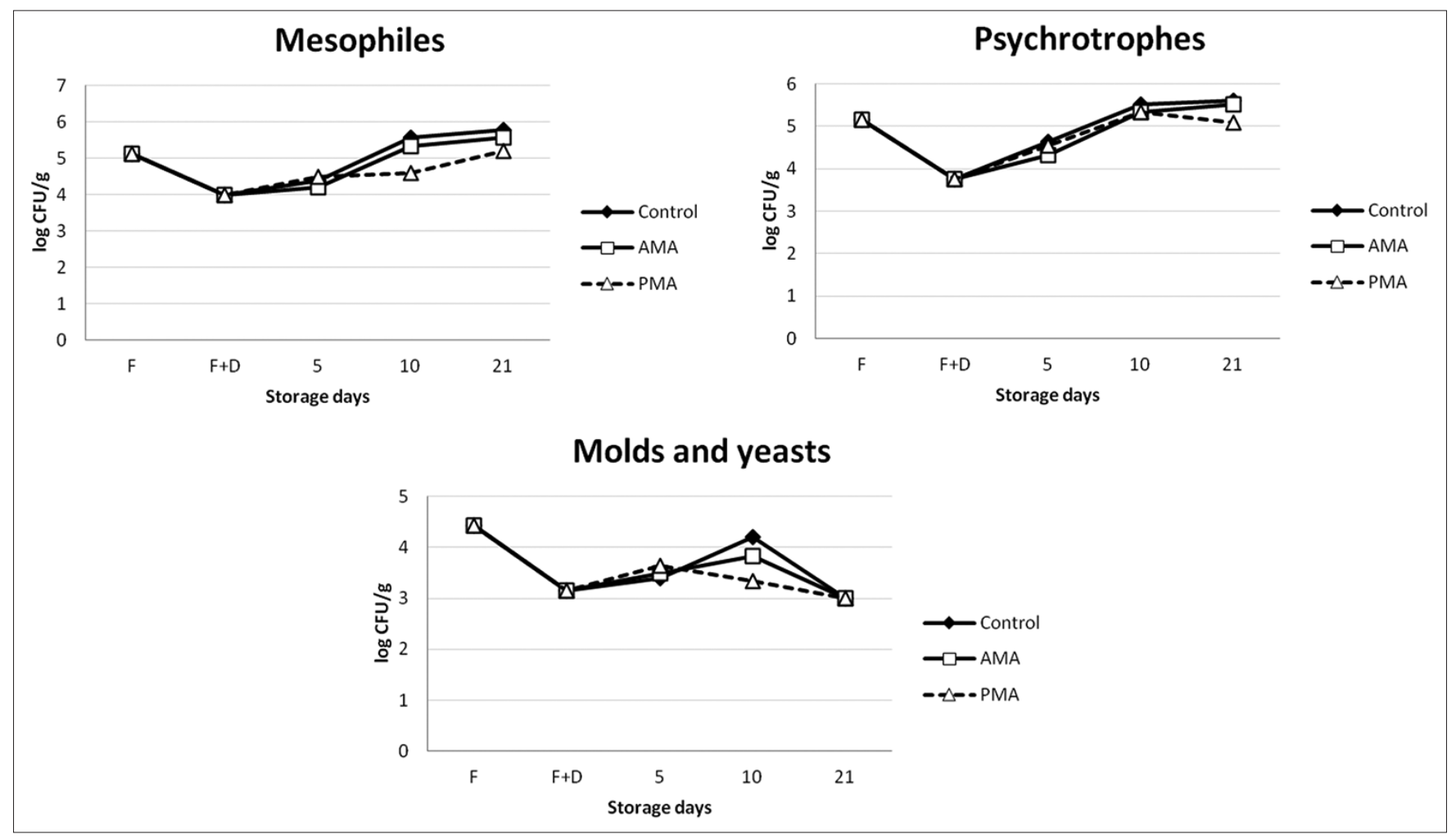

Fig 4. Microbial counts in Contrtol, AMA and PMA fresh-cut broccoli samples, before $(F)$ and after disinfection ( $F+D)$, and during storage $(n=3)$. 
Table 4: Results of the sensoryl test of control, AMA and PMA fresh-cut broccoli 'parthenon' at day 21 of storage at $5^{\circ} \mathrm{C}$

\begin{tabular}{lcccccc}
\hline Sampling date & \multicolumn{9}{c}{21} \\
Treatment & CONTROL & \multicolumn{2}{c}{ AMA } & \multicolumn{2}{c}{ PMA } \\
Sample & A & B & C & D & E & F \\
Rank sums (R) & 41 & 36 & 13.5 & 17.5 & 18 & 21 \\
R mean per treatment & \multicolumn{2}{c}{38.5} & \multicolumn{4}{c}{15.5} \\
Ftest & \multicolumn{4}{c}{46.67} & & 19.5 \\
\hline
\end{tabular}

presence of off-odors and a floret loose that gave them a poorest aspect.

\section{CONCLUSIONS}

Although heat treatment has been reported to be beneficial for chlorophyll retention, from our results it can be stated that it has a negative impact on sensory quality and shelflife of fresh cut broccoli florets. High respiration rate of broccoli florets allowed a quick modification of the inner packages atmosphere, so there were no differences between active and passive modified atmosphere treatments. Compared to air storage, modified atmosphere samples maintained a higher quality in terms of weight loss, color, chlorophylls, phenolic compounds, total antioxidant activity and sensory characteristics up to 21 days, under the studied conditions. Taking in account those results, passive modified atmosphere is the most suitable storage technique for fresh cut broccoli due to its simplicity and lower cost.

\section{ACKNOWLEDGMENTS}

P.F.A.H. thanks to the Fundación Carolina for her scholarship. D.B.G. and D.G.G. thank the Instituto Nacional de Investigación y Tecnología Agraria y Alimentaria (INIA) of Spain for their research contract.

\section{Authors' contributions}

PFAH was in charge of acquisition of data and preparation of the manuscript. DGG and MCAY were responsible of the design of the experiment and were involved in data interpretation. DBG was involved in the physico-chemical and sensory analysis. JDA did the microbiological analysis. MJBG was the project manager and was involved data analysis and revised the manuscript.

\section{REFERENCES}

Ansorena, M., N. Marcovich and S. Roura. 2011. Impact of edible coatings and mild heat shocks on quality of minimally processed broccoli (Brassica oleracea L.) During refrigerated storage. Postharvest Biol. Technol. 59(1): 53-63.

Brackett, R. E. 1989. Changes in the microflora of packaged fresh broccoli. J. Food Qual. 12: 169-181.

Büchert, A. M., P. M. Civello and G. A. Martínez. 2011. Effect of hot air, UV-C, white light and modified atmosphere treatments on expression of chlorophyll degrading genes in postharvest broccoli (Brassica oleracea L.) Florets. Sci. Hortic Amsterdam. 127(3): 214-219.

Caleb, O. J., K. Ilte, A. Fröhling, M. Geyer and P. V. Mahajan. 2016. Integrated modified atmosphere and humidity package design for minimally processed broccoli (Brassica oleracea L. var. Italica). Postharvest Biol. Technol. 121: 87-100.

Cano, A., J. Hernández-Ruiz, F. García-Cánovas, M. Acosta and M. B. Arnao. 1998. An end-point method for estimation of the total antioxidant activity in plant material. Phytochem. Anal. 9: 196-202.

Cantwell, M., J. Kang and G. Hong. 2003. Heat treatments control sprouting and rooting of garlic cloves. Postharvest Biol. Technol. 30: $57-65$.

Costa, M. L., P. M. Civello, A. R. Chaves and G. A. Martínez. 2005. Effect of hot air treatments on senescence and quality parameters of harvested broccoli (Brassica oleracea L. var Italica) heads. J. Sci. Food Agric. 85: 1154-1160.

Eason, J. R., D. J. Ryan, L. M. Watson, D. Hedderley, M. C. Christey, R. H. Braun and S. S. Coupe. 2005. Suppression of the cysteine protease, aleurain, delays floret senescence in Brassica oleracea. Plant Mol. Biol. 57: 645-657.

Eason, J. R., D. J. Ryan, B. Page, L. M. Watson and S. A. Coupe. 2007. Harvested broccoli (Brassica oleraceae) responds to high $\mathrm{CO}_{2}$ and low $\mathrm{O}_{2}$ atmosphere by inducing stress-response genes. Postharvest Biol. Technol. 43: 358-365.

Fernández-León, M., M. Lozano, M. C.Ayuso and D. González-Gómez. 2010. Fast and accurate alternative UV-chemometric method for the determination of chorophyll A and B in broccoli (Brassica oleracea Italica) and cabbage (brassica oleracea Sabauda) plants. J. Food Compost. Anal. 23(8): 809-813.

Fernández-León, M. F., A. M. Fernández-León, M. Lozano, M. C. Ayuso, M. L. Amodio, G. Colelli and D. González-Gómez. 2013a. Retention of quality and functional values of broccoli 'Parthenon' stored in modified atmosphere packaging. Food Control. 31: 302-313.

Fernández-León, M. F., A. M. Fernández-León, M. Lozano, M. C. Ayuso and D. González-Gómez. 2013b. Altered commercial controlled atmosphere storage conditions for 'Parhenon' broccoli plants (Brassica oleracea L. var. Italica). Influence on the outer quality parameters and on the health-promoting compounds. LWT-Food Sci. Technol. 50: 665-672.

Funamoto, Y., N. Yamauchi, T. Shigenaga and M. Shigyo. 2002. Effects of heat treatment on chlorophyll degrading enzymes in stored broccoli (Brassica oleracea L.). Postharvest Biol. Technol. 24: 163-170.

Hansen, M. E., H. Sorensen and M. Cantwell. 2001. Changes in acetaldehyde, ethanol and amino acid concentrations in broccoli florets during air and controlled atmosphere storage. Postharvest Biol. Technol. 22: 227-237.

Hong, G., G. Peiser and M. Cantwell. 2000. Use of controlled atmospheres and heat treatment to maintain quality of intact and minimally processed green onions. Postharvest Biol. Technol. 20: 53-61.

Izumi, H., A. E. Watada and W. Douglas. 1996. Optimum $\mathrm{O}_{2}$ or $\mathrm{CO}_{2}$ atmosphere for storing broccoli florets at various temperatures. J. Am. Soc. Hortic. Sci. 121: 127-131.

Jia, C., C. Xu, J. Wei, J. Yuan, G. Yuan, B. Wang and Q. Wang. 2009. Effect of modified atmosphere packaging on visual quality and glucosinolates of broccoli florets. Food Chem. 114(1): 28-37.

Lemoine, M., P. Civello, A. Chavez and G. Martínez. 2008. Effect of combined treatment with hot air UV-C on senescence and quality parameters of minimally processed broccoli (Brassica 
oleracea L. var. Italica). Postharvest Biol. Technol. 48: 5-21.

Lemoine, M., P. Civello, A. Chavez and G. Martínez. 2009. Hot air treatment delays senescence and maintains quality of freshcut broccoli florets during refrigerated storage. LWT-Food Sci. Technol. 42: 1076-1081.

Lin, C. M., J. M. Kim, W. X. Du and C. I. Wei. 2000. Bactericidal activity of isothiocyanate against pathogens on fresh produce. J. Food Prot. 63: 25-30.

Lucera, A., C. Costa, M. Mastromatteo, A. Conte and M. A. Del Nobile. 2011. Fresh-cut broccoli florets shelf-life as affected by packaging film mass transport properties. J. Food Eng. 102: 122-129.

Luna-Guzman, I., M. Cantwell and D. Barrett. 1999. Fresh-cut cantaloupe: Effects of $\mathrm{CaCl}_{2}$ dips and heat treatments on firmness and metabolic activity. Postharvest Biol. Technol. 17: 201-213.

Martínez-Hernández, G. B., F. Artés-Hernández, P. A. Gómez and F. Artés. 2013. Comparative behavior between kailan-hybrid and conventional fresh-cut broccoli throughout shelf-life. LWT-Food Sci. Technol. 50: 298-305.

Naes, T., P. B. Brockhoff and O. Tomic. 2010. Statistics for Sensory and Consumer Science, John Wiley \& Sons Ltd., Chichester, United Kingdom.

Nogales-Delgado, S., A. M. Fernández-León, J. Delgado-Adámez, M. T. Hernández-Méndez and D. Bohoyo-Gil. 2013. Effects of several sanitisers for improving quality attributes of minimally processed Fragaria vesca strawberry. Czech. J. Food Sci. 31(1): 49-54.

Olarte, C., S. Sanz, J. Echávarri and F. Ayala. 2009. Effect of plastic permeability and exposure to light during storage on the quality of minimally processed broccoli and cauliflower. LWT-Food Sci. Technol. 42: 402-411.

Perini, M. A., I. N. Sin, A. M. R. Jara, M. E. Gómez Lobato, P. M. Civello and G. A. Martínez. 2017. Hot water treatments performed in the base of the broccoli stem reduce postharvest senescence of broccoli (Brassica oleracea L. Var italic) heads stored at $20^{\circ} \mathrm{C}$. LWT-Food Sci. Technol. 77: 314-322.
Roura, S., L. Pereyra and C. D. Valle. 2008. Phenylalanine ammonia lyase activity in fresh cut lettuce subjected to the combined action of heat mild shocks and chemical additives. LWT-Food Sci. Technol. 41(5): 919-924.

Schreiner, M., P. Peters and A. Krumbein. 2007. Changes of glucosinolates in mixed fresh-cut broccoli and cauliflower florets in modified atmosphere packaging. J. Food Sci. 72: 585-589.

Serrano, M., D. Martínez-Romero, F. Guillén, S. Castillo and D. Valero. 2006. Maintenance of broccoli quality and functional properties during cold storage as affected by modified atmosphere packaging. Postharvest Biol. Technol. 39: 61-68.

Tsouvaltzis, P., A. Siomos and D. Gerasopoulos. 2006. Effect of hot water treatment on leaf extension growth, fresh weight loss and color of stored minimally processed leeks. Postharvest Biol. Technol. 39: 56-60.

Vallejo, F., C. García-Viguera and F. Tomás-Barberán. 2003. Health-promoting compounds in broccoli as influenced by refrigerated transport and retail sale period. J. Agric. Food Chem. 51: 3029-3034.

Verhoeven, D. T. H., R. A. Goldbohm, G. van Poppel, H. Verhagen and P. A. van den Brandt. 1996. Epidemiological studies on Brassica vegetables and cancer risk. Cancer Epidemiol. Biomarkers. 5: 733-748.

Viña, S. and A. Chaves. 2007. Effect of heat treatment and refrigerated storage on antioxidant properties of pre-cut celery (Apium graveolens L.). Int. J. Food Sci. Technol. 43(1): 44-51.

Yuan, G., B. Sun, J. Yuan and Q. Wang. 2010. Effect of 1-methylcyclopropene on shelf life, visual quality, antioxidant enzymes and health-promoting compounds in broccoli florets. Food Chem. 118: 774-781.

Zhang, D. and Y. Hamauzu. 2004. Phenolics, ascorbic acid, carotenoids and antioxidant activity of broccoli and their changes during conventional and microwave cooking. Food Chem. 88: 503-509.

Zhuang, H., D. F. Hildebrand and M. M. Barth. 1995. Senescence of broccoli buds is related to changes in lipid peroxidation. J. Agric. Food Chem. 43: 2585-2591. 